\title{
PROBLEMATIKA PROSES PEBELAJARAN ANAK BERKEBUTUHAN KHUSUS (AUTIS) DI KELAS III SD NEGERI 1 TUGU
}

\author{
Puput Riani1, Ratih Purnama Pertiwi2, dan Nesi Anti Andini3 \\ ${ }_{123}$ STKIP Nurul Huda Sukaraja \\ E-mail: ratihpp@stkipnurulhuda.ac.id
}

\begin{abstract}
Abstrak
Seluruh warga negara berhak mendapatkan pendidikan tanpa membedakan asal - usul, status sosial ekonomi, maupun keadaan fisik seseorang termasuk anak - anak yang memiliki kelainanan sebagaimana diamanatkan dalam UUD 1945 Pasal 31 ayat 1. . Berdasarkan latar belakang masalah penelitian yang dikemukakan di atas, maka peneliti tertarik untuk menganalisis bagaimana proses pembelajaran anak autis dan problematika apa saja yang dihadapi oleh guru dalam menangani anak berkebutuha khusus anak autis di SD Negeri 1 Tugu Harum. Penelitian ini menggunakan pendekatan kualitatif, dengan teknik analisis deskriptif pula, yaitu berupa reduksi data, penyajian data dan penarikan kesimpulan. Dalam proses pengumpulan data, penulis menggunakan teknik wawancara, observasi da dokumentasi. Adapun hasil dari penelitian ini dapat disimpulkan bahwa Proses pembelajaran di SD Negeri 1 Tugu Harum yaitu guru memberikan materi sesuai dengan kurikulum dari siswa reguler. Akan tetapi, tentu ada penyederhanaan untuk siswa autis seperti pada kemampuan bernalar. Problematika ketika proses pembelajaran siswa autis di SD Negeri 1 Tugu Harum yaitu problem sarana penunjang, ketidak ketercapaian pembelajaran, problem materi, problem motivasi, problem konsentrasi, problem pembelajaran ketika siswa autis tidak siap dalam proses pembelajaran atau menolak pembelajaran.
\end{abstract}

Kata kunci: Problematika Pembelajaran, ABK (Autis).

\section{PENDAHULUAN}

Perkembangan zaman saat ini semakin menunjukkan perhatian terhadap pendidikan anak. Pemerintah maupun masyarakat semakin sadar bahwa pendidikan merupakan hak semua anak, termasuk anak berkebutuhan khusus.Tantangan utama dalam melakukan pendidikan untuk anak berkebutuhan khusus adalah diperlukannya metode dan materi yang khusus sesuai dengan kemampuan dan kebutuhan anak.Pendidikan memegang peranan penting dalam kehidupan suatu negara untuk menjamin kelangsungan hidup berbangsa dan bernegara. Dalam sebuah pendidikan tentu ada proses pembelajaran. Kata pembelajaran berasal dari kata belajar mendapat awalan "pem" dan akhiran "an" menunjukkan bahwa adanya unsur dari luar (eksternal) yang bersifat "intervensi" agar terjadi proses belajar. Jadi pembelajaran merupakan upaya yang dilakukan oleh faktor eksternal agar terjadi proses belajar pada diri individu yang belajar. (Karwono, Mularsih,2017:19).

Setiap pembelajaran tentu ada problema yang dialami baik itu dari siswa ,guru atau yang lainnya. Pada dasarnya setiap anak berpotensi mengalami problema dalam belajarnya, hanya saja problem tersebut ada yang ringan, berat dan ada pula yang memerlukan perhatian khusus (children with special needs), memang setiap anak tidak selalu mengalami problematika dalam pembelajaran . Namun, ketika mereka diinteraksikan secara bersama - sama dengan teman sebaya dalam sistem pendidikan regular atau sekolah inklusi, ada hal - hal tertentu yang harus mendapat perhatian khusus dari guru dan sekolah untuk mendapatkan hasil yang optimal. (Gunarto,2013:1). Supaya dalam proses pembelajaran dikelas bisa maksimal dan membuahkan hasil maka kita harus mengetahui problem dalam proses pembelajaran dikelas yaitu : problem bisa berasal dari siswa, dari guru, kurang kreatifnya guru, tipe anak yang berbeda - beda, keterbatasan sarana dan prasarana yang ada disekolah. Anak berkebutuhan khusus (ABK) merupakan anak yang memiliki ciri yang berbeda dengan anak - anak pada umumnya, mereka mengalami hambatan dalam pertumbuhan dan perkembangannya. Mereka membutuhkan kegiatan dan layanan yang khusus agar dapat mencapai perkembangan yang optimal. (Jati Rinakri Atmaja , 2018 : 1). Anak autis adalah anak yang dalam 
perkembangannya terjadi hambatan. Anak autis mengalami hambatan perkembangan yang saling berhubungan dan terlihat sebelum berusia tiga tahun sehingga anak tersebut mengalami hambatan dalam komunikasi dan interaksi sosialnya. Anak autis masih perlu dibimbing dalam proses belajar tergantung bagaimana latihan, motivasi, pengalaman, lingkungan yang mengayomi mereka (Jurnal Penelitian Pendidikan Kebutuhan Khusus Volume 7 Nomor I, 2019. HIm 2 - 6 ISSN: Online 26225077. Pendidikan inklusi menurut Sapon-Shevin dalam O'Neil didefinisikan sebagai suatu sistem layanan pendidikan khusus yang mensyaratkan agar semua anak yang berkebutuhan khusus dilayani disekolah - sekolah terdekat dikelas biasa bersama teman-teman seusianya. Sejalan dengan konsep ini Smith mengemukakan ,bahwa inklusi dapat berarti penerimaan anak-anak yang mengalami hambatan kedalam kurikulum , lingkungan, interaksi sosial dan konsep diri (visi - misi) sekolah. Oleh karena itu perlu adanya restrukturisasi disekolah sehingga menjadi komunitas yang mendukung pemenuhan kebutuhan khusus bagi setiap anak.(Gunarto,2013:21). Sekolah di SDN 1 Tugu Harum,merupakan suatu sekolah seperti sekolah umum lainnya tetapi didalam sekolah tersebut ada beberapa anak berkebutuhan khusus yang juga ingin mendapatkan pendidikan yang layak seperti yang lainnya atau yang disebut dengan sekolah inklusi.Sekolah inklusi ini menerima siswa berkebutuhan khusus

\section{METODE/EKSPERIMEN}

Penelitian ini menggunakan pendekatan kualitatif. Atas dasar pemikiran diatas, maka penelitian ini menggunakan rancangan studi kasus, karena tujuan dari penelitian ini adalah untuk menggambarkan secara deskriptif bagaimana problematika pembelajaran siswa autis di SDN 1 Tugu Harum . Metode studi kasus yang dimaksud adalah studi kasus cross sectional, yakni penelitian dilakukan dengan waktu yang lebih singkat namun menjangkau populasi yang relatif lebih luas. Setiap penelitian di lapangan yang menggunakan pendekatan kualitatif, kehadiran peneliti tidak mungkin ditinggalkan karena peneliti sendiri yang mengumpulkan dan mengolah data, untuk selanjutnya menyusun laporan penelitian. Peneliti merupakan perencana, pelaksana pengumpulan data, analisis, penafsir data, dan pada akhirnya peneliti menjadi pelapor hasil penelitiannya. Pengertian instrumen atau alat penelitian di sini tepat karena ia menjadi segalanya dari keseluruhan proses penelitian.Berdasarkan pada pandangan di atas, maka pada dasarnya kehadiran peneliti disini disamping sebagai instrumen juga menjadi faktor penting dalam seluruh kegiatan penelitian ini. Peneliti berperan sebagai pengamat partisipan yang menjalankan dua peran sekaligus. Dalam melakukan penelitian ini, peneliti sudah terlebih dahulu melakukan observasi di lembaga terkait yaitu SDN 1 Tugu harum. Data merupakan bukti atau fakta dari suatu peristiwa yang digunakan sebagai bahan untuk memecahkan suatu permasalahan. Sumber data adalah sumber dari mana data akan digali. Apabila dilihat dari segi pentingnya data, maka sumber data dapat dibedakan menjadi dua macam, yaitu sumber data primer dan sumber data sekunder. Sumber primer dalam penelitian ini diperoleh dari obyek penelitian yaitu guru kelas III. Data yang dikumpulkan dalam penelitian ini diperoleh dari data lisan sebagai hasil wawancara, dokumentasi, dan hasil observasi. Sumber data sekunder adalah data-data yang diperoleh dari sumber kedua yang merupakan pelengkap, meliputi buku-buku yang menjadi referensi terhadap tema yang diangkat.Dengan adanya kedua sumber tersebut, diharapkan peneliti dapat mendeskripsikan tentang problematika pembelajaran anak berkebutuhan khusus autis. Sebagai upaya diperolehnya data secara holistik yang integratif, dan memperoleh relevansi data berdasarkan fokus dan tujuan penelitian, maka pengumpulan data dalam penelitian ini dilakukan dengan tiga teknik, yaitu : wawancara, observasi partisipan, dan studi dokumentasi. analisis data, yaitu:

a. Reduksi data (data reduction)

b. Penyajian Data

c. Penarikan Kesimpulan

Sebagai upaya pengecekan keabsahan data dari penelitian ini, peneliti menggunakan teknik 
triangulasi. Triangulasi dalam penelitian ini meliputi :

Triangulasi sumber data.

Triangulasi Data

Trianguasi Metode.

\section{HASIL DAN PEMBAHASAN}

Hasil

Analisis adalah mengelompokkan, membuat suatu urutan, memanipulasi serta menyingkatkan data sehingga mudah untuk di baca. Analisis digunakan untuk memahami hubungan dan konsep dalam data sehingga hipotesis dapat dikembangkan dan dievaluasi. Menurut Miles and Huberman, akitifitas dalam analisis data kulitatif dilakukan secara interaktif dan berlangsung secara terus menerus sampai tuntas, sehingga datanya sudah jenuh. Aktifitas dalam analisis data, yaitu:

a. Reduksi data (data reduction) Data yang diperoleh dari lapangan jumlahnya cukup banyak, untuk itu, maka perlu dicatat secara teliti dan rinci. b. Penyajian Data Setelah data direduksi, maka langkah selanjutnya adalah menyajikan data. Pada penelitian kualitatif ini disajikan berupa kalimat atau naratif. c. Penarikan Kesimpulan. Kesimpulan awal yang dikemukakan masih bersifat sementara dan akan berubah bila tidak ditemukan bukti-bukti yang kuat yang mendukung pada tahap pengumpulan data berikutnya, maka kesimpulan yang dikemukakan merupakan kesimpulan yang kredibel. Dengan demikian kesimpulan dalam penelitian kualitatif mungkin dapat menjawab rumusan masalah yang dirumuskan sejak awal.

\section{Proses Pembelajaran Siswa Autis Kelas III di SD Negeri 1 Tugu Harum}

Mengenai proses pembelajaran di SD Negeri 1 Tugu Harum, pihak sekolah memberikan bimbingan sesuai dengan kemampuan atau tingkatan masing-masing anak autis. Pembelajaran yang dilakukan seperti pembelajaran reguler, calistung, olahraga, cara bersosialisasi. Dalam setiap pembelajaran tentu ada aspek yang harus dipenuhi di antaranya penyampaian materi, media yang digunakan, metode pembelajaran dan evaluasi.

\section{Pemberian Materi}

Menurut hasil wawancara peneliti dengan guru kelas mengenai bagaimana proses pembelajaran siswa autis di kelas reguler, guru kelas menyampaikan bahwa:

"pembelajaran yang dilakukan di kelas reguler siswa autis diajarkan agar mampu bersosialisasi dengan teman yang lain. Seperti cara berbicara, bersikap di dalam kelas, duduk yang baik, dll. Jam pertama di mulai pukul 07.00-08.30. Sedangkan jam ketiga yaitu jam istirahat siswa autis terkadang berada di dalam kelas namun terkadang juga bermain di luar dengan siswa yang lain. Kemudian pada jam keempat sampai jam kedelapan siswa autis belajar di kelas reguler bersama siswa yang lain."(Hasil wawancara dengan guru kelas pada tanggal 04 Juni 2020 pukul 09.15 di SD Negeri 1 Tugu Harum).

Menurut hasil wawancara peneliti dengan ibu Khomsiah selaku guru bidang studi agama siswa autis, beliau menyampaikan bahwa:

" untuk pemberian materi kepada siswa autis ini, cara penyampaian materi yang saya berikan ke Galih dengan memberikan materi secara singkat/dirangkum.Penyampaian materi kepada siswa autis juga di sampaikan oleh guru bidang studi pjok yaitu bapak Agus Saparudin, beliau menyampaikan bahwa: "kalau materi untuk siswa autis penyampaiannya diringkas saja mbak biar mudah dimengerti oleh siswa autis".

\section{Media Yang Digunakan}

Menurut hasil wawancara peneliti dengan guru kelas mengenai media apa yang sesuai dengan kebutuhan anak autis guru kelas menyampaikan bahwa:

"media yang tepat itu biasanya media yang konkret, anak autis lebih suka belajar dengan media yang konkret"

Ibu Khomsiah selaku guru bidang studi agama juga menyampaikan bahwa:

"media yang saya gunakan ya media nyata karena untuk anak berkebutuhan khusus dia tidak 
bisa jika kita beri media yang tidak konkret, contohnya belajar wudhu beserta niatnya, jadi disitu guru harus benar-benar mencontohkan urutan-urutan wudhu yang benar dimulai dari membaca niat, berkumur dan sebagainya".

Bapak Agus Saparudin selaku guru bidang studi pjok juga menyampaikan bahwa:

"kalau untuk media kita pakai media nyata mbak, Alhamdulillah untuk medianya banyak tersedia di sekolah ini mbak, seperti bola kaki, raket, bola kasti, dan banyak lagi".

Menurut peneliti dari beberapa pemaparan di atas maka dapat disimpulkan bahwa media yang di gunakan dalam pembelajaran anak berkebutuhan khusus anak autis ini memang harus menggunakan media yang konkret atau nyata, karena anak autis akan lebih tertarik dengan media yang nyata, dengan adanya ketertarikan tersebut maka akan sedikit memudahkan guru dalam menyampaikan materi karena otomatis perhatian anak autis akan tertuju ke media yang digunakan.

\section{Metode Pembelajaran}

Menurut hasil wawancara peneliti dengan guru kelas, ternyata guru kelas menggunakan metode pendekatan emosional. Hal ini seperti yang di sampaikan oleh guru kelas kepada peneliti bahwa:

"saya menggunakan pendekatan emosional, karena kalau anak nyaman dengan kita mbak, insyaallah dia mau mengerjakan tugas yang kita berikan ya walaupun tidak maksimal ya mbak".

Ibu Khomsiah selaku guru bidang studi agama juga menyampaikan bahwa:

"saya tidak menggunakan metode khusus, hanya saja saya menggunakan cara bagaimana anak tersebut mau sekolah dan mendengarkan apa yang saya ucapkan, tujuannya agar walaupun hanya sedikit materi, tetapi tersimpan di memori anak tersebut, saya tidak memaksakan anak harus bias, karena jika di paksakan anak akan takut dan malah tidak mau sekolah".

Bapak Agus saparudin selaku guru bidang studi pjok menyampaikan bahwa:

"kalau untuk metode nya kami tidak memaksakan untuk anak autis mbak, sesekali cuma diberi arahan saja atau sesekali di perhatikan mbak, mereka mau sekolah saja sudah alhamdulillah mbak"

\section{Evaluasi}

Menurut hasil wawancara peneliti dengan guru kelas yaitu Ibu Sawiyah, beliau menyampaikan bahwa: "untuk penilaian hasil evaluasi anak autis ini kami hanya melakukan penilaian berdasarkan kepribadian saja, kami tidak menggunakan standar kkm".

Ibu Khomsiah selaku guru bidang studi agama juga menyampaikan terkait evaluasi bahwa:

"saya memberikan penilaian sesuai pengamatan sehari-sehari, tidak menggunakan kkm, karena jika menggunakan standar KKM jelas Galih tidak lulus, maka dari itu saya menggunakan pengamatan sehari-hari saja untuk si Galih ini".

Menurut Bapak Agus Saparudin selaku guru bidang studi pjok, beliau juga menyampaikan bahwa:

"kalau untuk evaluasi anak autis ini saya tidak memakai standar KKM di sekolah mbak, kami hanya memberikan nilai berdasarkan kepribadian saja mbak, mereka mau sekolah saja sudah alhamdulillah mbak".

Berdasarkan beberapa pendapat diatas maka peneliti menarik kesimpulan bahwa evaluasi yang dilakukan untuk anak berkebutuhan khusus anak autis tidak menggunakan standar kkm yang ada disekolah, penilaian hanya diberikan berdasarkan kepribadian dari guru kelas maupun guru bidang studi masing-masing saja. Karena jika menggunakan stadar kkm sudah pasti anak autis tidak mampu mencapai $\mathrm{kkm}$ yang sudah di tetapkan dari sekolah. Menurut Andi Prastowo kata pembelajaran adalah terjemahan dari instruction yang banyak di pakai dalam dunia pendidikan di Amerika Serikat. Istilah pembelajaran ini banyak di pengaruhi oleh aliran psikologi kognitif - wholistik, yang menempatkan siswa sebagai sumber kegiatan. (Andi Prastowo, 2013 : 55). Berdasarkan penelitian yang telah peneliti lakukan, apa yang telah dilakukan oleh pihak sekolah dan guru sesuai dengan teori yang ada yaitu "Mengenai hak setiap siswa atas perkembangan individu, sosial, dan 
intelektual. Para siswa harus di berikan kesempatan untuk mencapai potensi mereka. Untuk melakukannya, sistem pendidikan harus dirancang dengan memperhitungkan perbedaan yang besar antar siswa. Bagi mereka dengan kebutuhan belajar yang luar biasa dan memiliki ketidak mampuan khusus harus mempunyai akses terhadap pendidikan bermutu tinggi dan yang tepat". (MIF Baihaqi dan Sugiarmin, $2014: 75)$.

\section{Problematika Apa Saja Yang Dihadapi Oleh Guru Dan Solusi Dalam Pembelajaran Anak Berkebutuhan Khusus Anak Autis di SD Negeri 1 Tugu Harum \\ a. Problematika dalam proses pembelajaran anak berkebutuhan khusus anak autis di SD Negeri 1 Tugu Harum}

Setiap pembelajaran tentu ada kendala yang dialami baik itu kendala dari siswa, guru atau yang lain. Menurut kamus Bahasa Indonesia, problem berarti permasalahan dari suatu hal. Setiap orang memiliki problem atau masalah, tidak terkecuali seorang guru. Setiap guru mengalami problem masing-masing dan tentu berbeda.Berdasarkan hasil wawancara peneliti dengan pihak-pihak terkait, peneliti menemukan beberapa kendala yang di sampaikan oleh pihak-pihak terkait antara lain:

Ibu Sawiyah selaku guru kelas beliau menyampaikan kepada peneliti bahwa ada beberapa problematika dalam proses pembelajaran di antaranya:

"Pada awalnya pembelajaran untuk siswa autis dikelas reguler sangat mengganggu teman yang lain. Di kelas III anak autis yang bernama Galih sering teriak, tertawa tanpa sebab, juga selalu jalan-jalan mengambil barang milik temannya. Marah jika disuruh untuk menulis dan membaca. Begitu juga dengan siswa autis lainnya Fani yang selalu mengajak keluar kelas tidak mau didalam kelas akibatnya sering keluar masuk sehingga siswa yang lain menjadi terganggu karena perhatiannya tidak terfokus pada guru menjelaskan/ menerangkan pelajaran tetapi terfokus pada siswa autis tersebut. Kendala yang lain yaitu makan dan minum ketika pelajaran di kelas sehingga menimbulkan rasa iri siswa yang lainnya. Tidak hanya siswa yang merasa terganggu tapi guru kelas juga mengalami hal yang sama, yaitu merasa terganggu ketika pembelajaran di dalam kelas."(Hasil wawancara dengan guru kelas pada tanggal 04 Juni 2020 pukul 09.15 di SD Negeri 1 Tugu Harum).

Berikutnya guru kelas juga menyampaikan kepada peneliti sebagai berikut

"problem yang dihadapi guru itu adalah ketidak ketercapaian tujuan pembelajaran, guru belum bisa memenuhi target yang sudah tertera dalam standart kompetensi dan kompetensi dasar. "(Hasil wawancara dengan guru kelas pada tanggal 04 Juni 2020 pukul 09.15 WIB di SD Negeri 1 Tugu Harum).

Problem lain yang di hadapi oleh guru kelas adalah:

"problem materi yang dihadapi oleh guru kelas. Guru kelas mengalami masalah dalam mensingkronkan atau menyederhanakan pembelajaran kepada siswa autis tentang apa yang telah disampaikan".(Hasil wawancara dengan guru kelas pada tanggal 04 Juni 2020 pukul 09.15 WIB di SD Negeri 1 Tugu Harum).

Problematika tersebut juga disampaikan oleh guru bidang studi agama yaitu Ibu Khomsiah, beliau menyampaikan kepada peneliti bahwa:

"saya kadang susah dalam meringkas materi untuk diberikan kepada anak autis ini, karena kalau bertele-tele nanti anaknya tidak paham, kalau terlalu singkat nanti juga tidak ngerti”.(Hasil wawancara dengan guru bidang studi agama pada tanggal 04 Juni 2020 pukul 10.15 di SD Negeri 1 Tugu Harum).

Bapak Agus Saparudin selaku guru bidang studi pjok juga menyampaikan hal tersebut, beliau menyampaikan bahwa:

"ya repot mbak, karena harus meringkas lagi pembelajaran dengan kalimat atau bahasa yang mereka pahami mbak". (Hasil wawancara dengan guru bidang studi pjok pada tanggal 04 Juni 2020 pukul 10.45 di SD Negeri 1 Tugu Harum).

Guru kelas yaitu Ibu Sawiyah juga menyampaikan bahwa siswa juga mengalami problem motivasi

" siswa autis itu masih belum tumbuh sikap sadar diri untuk belajar dengan sungguh-sungguh 
tentang apa yang telah diajarkan oleh gurunya". (Hasil wawancara dengan guru kelas pada tanggal 04 Juni 2020 pukul 09.15 WIB di SD Negeri 1 Tugu Harum).

Guru bidang studi pjok juga menyampaikan hal yang sama terkait motivasi siswa autis ini, beliau menyampaikan bahwa

"anak autis ini motivasinya masih sangat rendah, kita sebagai guru sudah dengan semangat menyampaikan materi ternyata anaknya yang malas-malasan malah kadang sama sekali tidak mau belajar". (Hasil wawancara dengan guru bidang studi pjok pada tanggal 04 Juni 2020 pukul 10.45 di SD Negeri 1 Tugu Harum).

Ibu Sawiyah selaku guru kelas juga menyampaikan kepada peneliti, problem pembelajaran di kelas yang dihadapi guru pada saat guru sedang mengajar yaitu

"belum bisanya siswa autis dalam memusatkan perhatiannya pada saat pembelajaran sedang berlangsung, kurangnya fokus perhatian siswa terhadap gurunya. Dan siswa autis juga sering mengganggu teman yang lainya".(Hasil wawancara dengan guru kelas pada tanggal 04 Juni 2020 pukul 09.15 di SD Negeri 1 Tugu Harum).

Bapak Agus Saparudin selaku guru bidang studi pjok juga menyampaikan kepada peneliti bahwa:

"anak autis ini susah dalam pembelajaran karena mereka tidak bisa konsentrasi atau tidak fokus dalam pembelajaran".(Hasil wawancara dengan guru kelas pada tanggal 04 Juni 2020 pukul 10.45 di SD Negeri 1 Tugu Harum).

Terkait media Bapak Agus Saparudin juga menyampaikan bahwa:

"kalau diberi media memang anak autis ini fokus nya ke media nya tetapi kita harus pandaipandai mengambil perhatian mereka agar dapat memperhatikan kita juga dalam memberikan pembelajaran melalui media". (Hasil wawancara dengan guru kelas pada tanggal 04 Juni 2020 pukul 10.45 di SD Negeri 1 Tugu Harum).

Menurut Ibu Khomsiah selaku guru bidang studi agama beliau menyampaikan bahwa:

"anak ini tidak bisa berkonsentrasi, maka nya kita kasih media nyata, tapi jika di kasih media nyata yang menarik juga kadang mereka malah lebih fokus ke media nya bukan ke materinya, contohnya belajar wudhu, mereka malah asik bermain air nya, bukan fokus ke materinya".(Hasil wawancara dengan guru kelas pada tanggal 04 Juni 2020 pukul 10.15 di SD Negeri 1 Tugu Harum).

Menurut Chandler dan petty yang dikutip oleh Handri Sulistiowati (Handri Susilowati.(2012). Problematika Guru DalamPembelajaran Bahasa Indonesia Materi Bercerita Terdapat Siswa Autis di MI Sunan Giri).

bahwa masalah-masalah yang dihadapi guru pada umumnya sebagai berikut:

1. Kebutuhan akan pembelajaran/tempat tinggal yang sesuai atau wajar bagi seorang guru.

2.Memperoleh perkenalan dengan personel sekolah (guru-guru dan pegawai).

3. Memperoleh pengertian tentang system dan tujuan sekolah.

4. Mengerti tentang peraturan-peraturan dan tata tertib yang berlaku disekolah itu.

5. Mengerti dan mengenal masyarakat serta lingkungan sekitar.

6. Mengenal organisasi-organisasi professional dan etika jabatan

7.Masalah-masalah penting lainnya yang berhubungan langsung dengan tugas pekerjaanya sebagai guru disekolah itu.

Menurut Robin L. Gabriels (Ichsan, M., \& Iswari, M. (2019).Pelaksanaan Pembelajaran IPA bagi Anak Autis di Sekolah Penyelenggara Pendidikan Inklusi. Jurnal Penelitian Pendidikan Khusus, volume 7 nomor 1,ISSN 243-248.)

yang dikutip dalam thesis Hayyan Ahmad Ulul Albab dalam thesisnya menjelaskan tentang problem siswa autis yang akan dihadapi pada saat usia sekolah dan remaja. Beberapa permasalahnnya yaitu:
a. Communication Abilities
b. Social Skills
c. Behavior Problems 


\section{d. Adaptive Living Skills .}

Berdasarkan penelitian yang telah peneliti lakukan, problematika dalam proses pembelajaran anak berkebutuhan khusus anak autis di SD Negeri 1 Tugu Harum yang berkaitan dengan sarana penunjang, ketidak ketercapaian pembelajaran, dan problem materi sesuai dengan teori yang di gunakan oleh peneliti dalam penelitian ini yaitu :

Menurut Chandler dan petty yang dikutip oleh Handri Sulistiowati (Handri Susilowati.(2012). Problematika Guru DalamPembelajaran Bahasa Indonesia Materi Bercerita Terdapat Siswa Autis di MI Sunan Giri).

bahwa masalah-masalah yang dihadapi guru pada umumnya sebagai berikut:

1. Kebutuhan akan pembelajaran/tempat tinggal yang sesuai atau wajar bagi seorang guru.

2.Memperoleh perkenalan dengan personel sekolah (guru-guru dan pegawai).

3. Memperoleh pengertian tentang system dan tujuan sekolah.

4. Mengerti tentang peraturan-peraturan dan tata tertib yang berlaku disekolah itu.

5. Mengerti dan mengenal masyarakat serta lingkungan sekitar.

6. Mengenal organisasi-organisasi professional dan etika jabatan

7. Masalah-masalah penting lainnya yang berhubungan langsung dengan tugas pekerjaanya sebagai guru disekolah itu.

Problematika lain dalam proses pembelajaran yaitu yang berkaitan dengan motivasi, konsentrasi, dan ketidak siapan siswa autis dalam proses pembelajaran ternyata juga sesuai dengan teori yang ada yaitu: Menurut Robin L. Gabriels (Ichsan, M., \& Iswari, M. (2019).Pelaksanaan Pembelajaran IPA bagi Anak Autis di Sekolah Penyelenggara Pendidikan Inklusi. Jurnal Penelitian Pendidikan Khusus, volume 7 nomor 1,ISSN 243-248.) yang dikutip dalam thesis Hayyan Ahmad Ulul Albab dalam thesisnya menjelaskan tentang problem siswa autis yang akan dihadapi pada saat usia sekolah dan remaja. Beberapa permasalahnnya yaitu:
a. Communication Abilities
b. Social Skills
c. Behavior Problems
d. Adaptive Living Skills

\section{Pembahasan}

Solusi Dalam Menghadapi Problematika Pembelajaran Anak Berkebutuhan Khusus Anak Autis di SD Negeri 1 Tugu Harum

Berkaitan dengan problematika proses pembelajaran siswa autis di SD Negeri 1 Tugu Harum terdapat beberapa solusi yang dilakukan oleh peneliti, guru kelas maupun pihak sekolah. Meskipun untuk tiap-tiap jenis dan jenjang pendidikan masing-masing memiliki kekhususan, namun pada dasarnya pemecahan masalah bersasaran pada perbaikkan kualitas upaya tersebut dapat meningkatkan kualitas proses pendidikan dan pengalaman belajar peserta didik khususnya siswa autis, agar proses belajar mengajar dapat berjalan dengan optimal.

Berdasarkan hasil penelitian yang peneliti lakukan maka peneliti dan pihak sekolah menemukan solusi dalam menghadapi problematika pembelajaran anak berkebutuhan khusus anak autis yaitu:

Pembelajaran untuk anak autis di dalam kelas III di SD Negeri 1 Tugu Harum yang dilakukan oleh pendidik dalam meningkatkan kualitas pembelajaran harus didukung dengan sumber daya dan sarana yang memadai. Berikut seperti yang di sampaikan oleh ibu Sawiyah kepada peneliti sebagai berikut solusi dalam menghadapi problem ketidak ketercapaian tujuan pembelajaran, guru belum bisa memenuhi target yang sudah tertera dalam standart kompetensi dan kompetensi dasar yaitu :

"Setiap hari Sabtu guru-guru dan pihak sekolah melakukan kegiatan pelatihan dengan metode lesson study ataubisa dinamakan dengan in house training dan guru melakukan pemahaman dari hasil dari observasi, identifikasi dan asesmen".(Hasil wawancara dengan guru kelas pada tanggal 04 Juni 2020 pukul 09.15 di SD Negeri 1 Tugu Harum).

Solusi dalam menghadapi problem materi, yang dihadapi guru kelas,guru bidang studi agama 
dan guru bidang studi pjok yaitu guru kelas dang guru bidang studi lainnya yang mengalami masalah dalam mensingkronkan atau menyederhanakan pembelajaran kepada siswa autis tentang apa yang telah disampaikan.

"Solusinya yaitu guru menyederhanakan materi pembelajaran yang terdapat di buku pelajaran kemudian ditulis ulang di papan tulis oleh guru dengan bahasanya sendiri yang mana bahasa itu hasil dari rangkuman atau kesimpulan dari materi pelajaran sehingga para siswa bisa lebih mudah untuk memahami apa yang akan dijelaskan oleh gurunya saat semua siswa telah selesai menulis."(Hasil wawancara dengan guru kelas dan guru bidang studi agama dan pjok pada tanggal 04 Juni 2020 pukul 09.15 di SD Negeri 1 Tugu Harum).

Solusi dalam menghadapi problem motivasi, siswa autis yang masih belum tumbuh sikap sadar diri dalam fikiran siswa autis untuk belajar dengan sungguh-sungguh tentang apa yang telah diajarkan oleh gurunya.

"Solusinya yaitu guru harus bisa menanamkan sikap bahwa semua siswa autis itu seperti siswa normal pada umumnya dengan menerima semua kekurangannya sehingga dengan kekurangannya itu para guru bisa membimbingsiswa autis ke arah yang lebih baik. Sebenarnya dari pihak guru maupun pihak sekolah di SD Negeri 1 Tugu Harum dari hasil wawancara sudah melakukan beberapa usaha/upaya untuk mengatasinya problematika diantaranya dengan mengikuti pelatihanpelatihan di forum-forum tertentu.(Hasil wawancara dengan guru kelas pada tanggal 04 Juni 2020 pukul 09.15 di SD Negeri 1 Tugu Harum).

Ibu Sawiyah selaku guru kelas III juga mengungkapkan kepada peneliti solusi dalam mengahadapi problem konsentrasi siswa autis adalah sebagai berikut

"Solusi dalam menghadapi problem konsentrasi, yang dihadapi oleh guru yaitu belum bisanya siswa autis dalam memusatkan perhatiannya pada saat pembelajaran sedang berlangsung, kurangnya fokus perhatian siswa terhadap gurunya. Solusinya yaitu dengan melakukan program layanan pembelajaran dan program layanan kekhususan. Seperti menyederhanakan materi pelajaran, jelaskan dengan cara yang santai dan gunakan bahasa yang dia mengerti dan terus dampingi agar dia merasa nyaman dengan kita" (Hasil wawancara dengan guru kelas pada tanggal 04 Juni 2020 pukul 09.15 di SD Negeri 1 Tugu Harum).

Guru kelas dan guru bidang studi agama juga menyampaikan kepada peneliti bahwa usaha yang ditempuh dalam mengelola kelas untuk meningkatkan konsentrasi belajar siswa autis khususnya usaha yang dilakukan melalui fasilitas belajar adalah

"dengan mengatur ruang belajar agar siswa merasa nyaman dikelas. Selain itu usaha yang dilakukan adalah dengan memberikan media pembelajaran kepada siswa autis."(Hasil wawancara dengan guru kelas dan guru bidang studi agama pada tanggal 04 Juni 2020 pukul 09.15 di SD Negeri 1 Tugu Harum).

Solusi dalam menghadapi problem ketika siswa sedang tidak mood atau menolak pembelajaran.

"Solusinya yaitu guru lebih banyak melakukan kegiatan membimbing dengan pendekatan interaksi antara siswa dan guru kelas sehingga guru bisa mengidentifikasi apa saja kekurangan yang dihadapi oleh siswa autis." (Hasil wawancara dengan guru kelas dan guru bidang studi agama dan pjok pada tanggal 04 Juni 2020 pukul 09.15 di SD Negeri 1 Tugu Harum).

Berdasarkan solusi-solusi yang sudah di lakukan oleh guru kelas ternyata solusi yang dilakukan sesuai dengan teori yang peneliti gunakan dalam penelitian ini yaitu:

Menurut Jati Rinakri Atmaja (Jati Rinakri Atmaja 2018 : 223) dalam proses pembelajaran anak berkebutuhan khusus anak autis ada beberapa strategi di antaranya sebagai berikut:

Perencanaan pembelajaran hendaknya dibuat berdasarkan hasil assessment dan di buat bersama antara guru kelas dan guru khusus dalam bentuk program pembelajaran individual (IEP)

Pelaksanaan pembelajaran lebih mengutamakan metode pembelajaran kooperatif dan partisipatif, memberi kesempatan yang sama dengan peserta didik yang lain, menjadi tanggung jawab bersama dan di laksanakan secara kolaborasi antara guru kelas, serta dengan menggunakan 
media, sumber daya dan lingkungan yang beragam sesuai dengan keadaan. (Jati Rinakri Atmaja $2018: 223)$

Berdasarkan hasil wawancara dan dokumentasi maka peneliti menarik kesimpulan dari solusi yang telah peneliti paparkan di atas, solusi yang dilakukan oleh pihak sekolah dan guru untuk mengatasi problematika pembelajaran bagi siswa autis di SD Negeri 1 Tugu Harum yaitu untuk sementara memanfaatkan sarana yang ada disekolah saja. Setiap hari Sabtu guru-guru dan pihak sekolah melakukan kegiatan pelatihan dengan metode lesson study. Guru menyederhanakan materi pembelajaran yang terdapat di buku pelajaran. Guru harus bisa menanamkan sikap bahwa semua siswa autis itu seperti siswa normal pada umumnya. Guru lebih banyak melakukan kegiatan membimbing dengan pendekatan interaksi antara siswa dan guru kelas sehingga guru kelas bisa mengidentifikasi apa saja kekurangan yang dihadapi oleh siswa autis.

\section{PENUTUP}

Hasil pemaparan data dan analisis diatas maka dapat disimpulkan bahwa:

Proses pembelajaran di SD Negeri 1 Tugu Harum yaitu guru memberikan materi sesuai dengan kurikulum dari siswa reguler. Akan tetapi, tentu ada penyederhanaan untuk siswa autis seperti pada kemampuan bernalar. Problematika ketika proses pembelajaran siswa autis di SD Negeri 1 Tugu Harum yaitu problem sarana penunjang, ketidak ketercapaian pembelajaran, problem materi, problem motivasi, problem konsentrasi, problem pembelajaran ketika siswa autis tidak siap dalam proses pembelajaran atau menolak pembelajaran. Solusi yang dilakukan oleh guru untuk mengatasi problematika pembelajaran bagi siswa autis di SD Negeri 1 Tugu Harum yaitu berdasarkan hasil wawancara, dokumentasi dan observasi maka peneliti menarik kesimpulan yaitu yang pertama solusi problem minimnya sarana prasarana yaitu untuk sementara memanfaatkan sarana yang ada disekolah saja karena biayanya juga mahal. Dua, problem ketidak ketercapaian tujuan pembelajaran, setiap hari Sabtu guru-guru dan tenaga - tenaga professional melakukan kegiatan pelatihan dengan metode lesson study atau bisa dinamakan dengan in house training dan guru melakukan pemahaman dari hasil dari observasi, identifikasi dan asesmen untuk siswa berkebutuhan khusus. Tiga, solusi problem materi, guru menyederhanakan materi pembelajaran yang terdapat di buku pelajaran kemudian ditulis ulang di papan tulis oleh guru dengan bahasanya sendiri. Sehingga para siswa autis mudah memahami. Empat, problem motivasi, guru harus bias menanamkan sikap bahwa semua siswa autis itu seperti siswa normal pada umumnya dengan menerima semua kekurangannya sehingga dengan kekurangannya itu para guru bias membimbing siswa autis ke arah yang lebih baik. Lima, problem konsentrasi, guru harus melakukan program layanan pembelajaran dan program layanan kekhususan untuk siswa autis. Enam, problem pembelajaran ketika siswa autis tidak siap dalam proses pembelajaran atau menolak pembelajaran, guru lebih banyak melakukan kegiatan membimbing dengan pendekatan interaksi antara siswa dan guru kelas sehingga guru kelas bisa mengidentifikasi apa saja kekurangan yang dihadapi oleh siswa autis.

\section{DAFTAR PUSTAKA}

Agustin Ina . (2016). Manajemen pendidikan Inklusi di Sekolah Dasar Sumbersari 1 kota Malang. Education and Human Development Journal, Vol.01, No. 01.

Ali Muhammad, Asrori M. 2009. Psikologi Remaja. Jakarta : BumiAksara.

Atmaja, Jati Rinakri. 2017. Pendidikan dan Bimbingan Anak Berkebutuhan Khusus. Bandung : PT Remaja Rosdakarya.

Baihaqi, MIF dan Sugiarmin. 2014. Memahami dan Membantu Anak ADHD. Bandung : Refika Aditama.

Ballerina, T. 2016. Meningkatkan Rentang Perhatian Anak Autis Dalam Pembelajaran Pengenalan Huruf. Journal of Disability Studies . vol. 3, No. 2, ISSN.245-266.

Bashir, A, et al. 2014. Challenge Faced by Families of Autistic Children. International Journal of Interdisciplinary research and Innovation. Vol. 2, Issue 1, PP : 64-68.

Bujang, N. A, Jima'ain, M. T., \& Saari, Z. 2020. Penerapan Konsep IKHLAS Dalam Menyantuni Anak 
Istimewa (Autisme) (Implementation of IKHLAS Concept In Treating Special Needs). UMRANInternational Journal of Islamic and Civilization Studie. Vol 6 No 3-2.

Gunarto. 2013. Pendidikan Anak Berkebutuhan Khusus. Semarang : Unissula Press.

Ichsan, M., \& Iswari, M. 2019. Pelaksanaan Pembelajaran IPA Bagi Anak Autis di Sekolah Penyelenggara Pendidikan Inklusi. Jurnal Penelitian Pendidikan Khusus. Vol. 7, No. 243-248.

Idi Abdullah. 2016. Pengembangan Kurikulum Teori dan Praktek. Jogjakarta : Ar - Ruzz Media.

Karwono, Mularsih Heni. 2017. Belajar dan Pembelajaran Serta Pemanfaatan Sumber Belajar. Depok:Rajawali Pers.

Mayzan Ichsan, Mega Iswari. 2019. Pelaksanaan Pembelajaran IPA Bagi Anak Autis di Sekolah Penyelenggara Pendidikan Inklusi. Jurnal Penelitian Pendidikan Kebutuhan Khusus. Vol .7, No. 1. HIm 2-6 ISSN : Online 2622-5077.

Padmadewi, N. N., \& Artini, L.P. 2017. Teaching English to a Student With Autism Spectrum Disorder in Reguler Classroom in Indonesia. International Journal of Instruction, 10 (3), 159-176. ISSN 1694-609X.

Prastowo, Andi. 2013. Pengembangan Bahan Ajar Tematik. Jogjakarta : Diva Press.

Purwanta, Edi. 2012. Modifikasi Perilaku Alternatif Penanganan Anak Berkebutuhan Khusus. Yogyakarta : Pustaka Pelajar.

Ratih, Y. 2016. Analisis Faktor Yang Berhubungan dengan Praktik Pendidikan Seks oleh Ibu yang Memiliki Anak Autis Usia Remaja (studi di SLB Negeri Kota Semarang). Jurnal Kesehatan Masyarakat (e-journal), 4(2), 238-246.

Rusman. 2016. Model - Model Pembelajaran. Jakarta : Rajawali Pers.

Saichu, A. C.,\& Listiyandini, R. A. 2018. Pengaruh Dukungan Keluarga dan Pasangan Terhadap reseliensi Ibu yang Memiliki Anak dengan Spektrum Autisme. Psikodimensia, 17(1), 1-9.

Santoso, M. B.,\& Rachmasari, Y. 2017. Peran Pekerja Sosial Dalam Penanganan Anak Autis. Share:Social Work Journal, 7(2), 38-45.

Sari, N. 2016. Jurnal Bimbingan dan Konseling Indonesia Vol 1, No 2 November 2016. Hal 31-35 pISSN : 2477-5916 e-ISSN : 2477-8370.

Suprijono Agus. 2015. Cooperative Learning Teori \& Aplikasi Paikem. Yogyakarta : Pustaka Pelajar.

Tarnoto, N. 2016. Permasalahan - Permasalahan yang dihadapi Sekolah Penyelenggara Pendidikan Inklusi Pada Tingkat Sd. Humanitas : Jurnal Psikologi Indonesia, Vol 13 No 1, 50-61 ISSN 26225077.

Usop, D. S. 2014. Model Pendidikan Yang Diberikan Oleh Guru Pada Anak Autis di SLB Negeri 1 Palangka Raya. Anterior Jurnal, Vol 13 No 2, 198-204. 